\title{
SUMBER INFORMASI COVID-19 BAGI IBU HAMIL DAN IBU NIFAS DI KECAMATAN BATURRADEN
}

\author{
Diki Retno Yuliani \\ Poltekkes Kemenkes Semarang \\ email: dikiretnoyuliani@gmail.com
}

\begin{abstract}
Pregnant women and post-partum women are vulnerable groups during the COVID-19 pandemic. COVID-19 prevention behavior in pregnant women can be influenced by sources of information that convey about COVID-19. The purpose of this study was to describe the sources of information on COVID-19 for pregnant women and post-partum mothers in Baturraden District. This study was a descriptive study. The sample were 30 pregnant women and 23 post-partum mothers in the Baturraden sub-district using a cluster sampling technique. Data collection in October 2020, used the google form research instrument. The results obtained were that the most accessible sources of information on COVID-19 by pregnant women and post-partum mothers in Baturraden District were television and social media, the largest number of sources of information on COVID-19 accessed by pregnant women were one and two sources of information, the largest number of sources of information for COVID-19 accessed by post-partum mothers was one source of information. Pregnant women and postpartum mothers must access more sources of information and consider the truth in order to obtain factual, valid and relevant information.
\end{abstract}

Keywords: source of information on covid-19; pregnant woman; postpartum

\begin{abstract}
ABSTRAK
Ibu hamil dan ibu nifas adalah kelompok rentan pada masa pandemi COVID-19. Perilaku pencegahan COVID-19 pada ibu hamil dapat di pengaruhi oleh sumber informasi yang menyampaikan tentang COVID-19. Tujuan penelitian ini untuk mengetahui gambaran sumber informasi COVID-19 bagi ibu hamil dan ibu nifas di Kecamatan Baturraden. Studi ini merupakan penelitian deskriptif, dengan sampel 30 ibu hamil dan 23 ibu nifas di kecamatan Baturraden dengan teknik cluster sampling. Pengumpulan data pada bulan Oktober 2020, dengan instrumen penelitian google form. Hasil yang diperoleh adalah sumber informasi tentang COVID-19 yang terbanyak diakses oleh ibu hamil dan ibu nifas di Kecamatan Baturraden adalah televisi dan sosial media, jumlah sumber informasi COVID-19 yang di akses oleh ibu hamil terbanyak adalah satu dan dua sumber informasi, jumlah sumber informasi COVID-19 yang diakses ibu nifas terbanyak adalah satu sumber informasi. Ibu hamil dan ibu nifas harus mengakses lebih banyak sumber informasi dan mempertimbangkan kebenarannya agar mendapatkan informasi yang faktual, valid dan relevan.
\end{abstract}

Kata Kunci: sumber informasi covid-19; ibu hamil; ibu bersalin

\section{Pendahuluan}

COVID-19 telah ditetapkan sebagai bencana nasional non alam (Direktorat Kesehatan Keluarga, 2020), angka kejadian COVID-19 di Indonesia cukup tinggi, yaitu tercatat 1.718 .575 terkonfirmasi positif dan 47.218 meninggal sejak 2 maret 2020 sampai 11 Mei 2021. Provinsi Jawa Tengah adalah peringkat ke 3 terbanyak dengan 188.065 kasus terkonfirmasi positif COVID-19 atau 10,9 \% dengan 8.580 orang 
meninggal dunia (Satuan Tugas Penanganan COVID-19, 2021).

Ibu hamil adalah salah satu kelompok rentan, karena perubahan sistem kekebalan tubuh pada ibu hamil berhubungan dengan gejala infeksi COVID-19 yang lebih berat (POKJA Infeksi Saluran Reproduksi PP POGI, 2020). Sedangkan pada ibu nifas menyusui, dapat menularkan COVID-19 pada bayi, karena kontak erat bayi dengan ibu ketika menyusui merupakan risiko utama terjadinya penularan COVID-19 dari ibu ke bayi melalui droplet infeksius (Kemenkes, 2020). Prinsip pencegahan COVID-19 pada ibu hamil dan ibu nifas adalah dengan universal precaution, meliputi cuci tangan memakai sabun selama 20 detik atau menggunakan handsanitizer, memakai alat pelindung diri dan menjaga kondisi tubuh dengan istirahat cukup, rajin olahraga, makan dengan gizi seimbang dan mempraktikan etika batuk-bersin (Direktorat Kesehatan Keluarga, 2020).

Perilaku pencegahan COVID-19 pada ibu hamil dapat di pengaruhi keluarga, masyarakat serta media informasi yang menyampaikan tentang COVID-19 (Dewi et al., 2020). Perubahan perilaku mencakup 3 ranah perilaku yaitu pengetahuan, sikap dan ketrampilan melalui proses pendidikan kesehatan (perilaku sehat). Perilaku sehat dapat berupa pengetahuan yang baik, pikiran yang sehat, emosi yang positif dan keinginan yang realistis (Mubarak \& Chayatin, 2009).

UNICEF melaksanakan survei di 6 Kota besar di Indonesia tentang praktik pencegahan COVID-19 meliputi $3 \mathrm{M}$ (mencuci tangan, memakai masker dan menjaga jarak). Hasil menunjukkan bahwa $72 \%$ mencuci tangan, $71 \%$ memakai masker dan hanya $47 \%$ yang menjaga jarak. Rendahnya prosentase penerapan menjaga jarak sejalan dengan kurangnya pengetahuan tentang pencegahan penularan COVID-19, salah satunya pengetahuan tentang penularan COVID-19 dapat terjadi pada saat berbicara atau bernafas, sehingga masyarakat merasa tidak perlu menjaga jarak ketika lawan bicara tidak batuk ataupun bersin. Sosialisasi tentang pencegahan COVID -19 telah dilakukan oleh Pemerintah dan berbagai Lembaga, namun karena banyak informasi palsu (hoax) yang beredar menyebabkan banyak masyarakat yang masih belum memahaminya (Siregar et al., 2020). Sumber informasi tentang COVID-19 yang dipercayai oleh masyarakat meliputi televisi, koran, radio, media sosial, WhatsApp Group, pemberitaan media online, dan situs internet. Untuk mengubah perilaku pencegahan COVID-19 pada masyarakat agar lebih disiplin, diperlukan edukasi lebih lanjut melalui akses terhadap sumber-sumber informasi yang dapat dipertanggung jawabkan (Tim Komunikasi KPCPEN, 2020).

Sebuah studi pada ibu hamil melaporkan bahwa mayoritas ibu hamil memiliki pemahaman yang kurang tentang upaya pencegahan infeksi COVID-19 (Siregar et al., 2020). Namun hal tersebut tidak sejalan dengan sebuah studi yang menyatakan bahwa mayoritas ibu hamili trimester III memiliki pengetahuan yang baik tentang pencegahan COVID-19 (Dewi et al., 2020). Studi pada ibu nifas melaporkan bahwa mayoritas ibu nifas memiliki pengetahuan yang baik tentang upaya pencegahan COVID-19 (Hutagaol \& Sihotang, 2020). Pengetahuan tentang pencegahan COVID-19 pada ibu hamil dan ibu nifas dapat dipengaruhi oleh sumber informasi yang di dapat. Sebuah studi melaporkan bahwa sumber informasi berhubungan secara signifikan dengan pengetahuan masyarakat tentang COVID-19 (Yunus \& Zakaria, 2021). Tujuan studi ini adalah untuk mengetahui sumber informasi COVID-19 bagi ibu hamil dan ibu nifas di Kecamatan Baturraden. Ketika sudah diketahui sumber informasi apa yang paling banyak di akses, dapat menjadi pertimbangan tenaga kesehatan dalam memberikan informasi seputar COVID-19 dan bagaimana manajemennya selama kehamilan, persalinan, nifas dan menyusui kepada ibu hamil dan ibu nifas khususnya di wilayah Kecamatan Baturraden.

\section{Metode Penelitian}

Penelitian ini adalah penelitian deskriptif. Populasi target dalam penelitian ini yaitu ibu hamil dan ibu nifas di Kabupaten Banyumas dengan populasi terjangkau ibu hamil dan ibu nifas di Kecamatan Baturraden. Sampel yang diteliti yaitu 30 ibu hamil dan 23 
ibu nifas di Wilayah Kecamatan Baturraden yang diambil secara cluster. Responden ibu hamil dipilih dari masing-masing dua Desa di wilayah kerja Puskesmas I Baturraden dan Puskesmas II Baturraden, sedangkan responden ibu nifas dipilih dari masing-masing empat Desa di wilayah kerja Puskesmas I Baturraden dan Puskesmas II Baturraden.

Responden yang memenuhi kriterian inklusi dan eksklusi di jadikan sampel. Adapun kriterian inklusinya yaitu bersedia mengikuti penelitian secara daring (online), sedangkan kriteria eksklusinya yaitu tidak mempunyai aplikasi whatsapp, tidak mempunyai android dan tidak dapat mengakses google form.

Pengumpulan data dilaksanakan pada bulan Oktober 2020 melalui pengisian kuesioner (google form) tentang sumber informasi COVID - 19. Ibu hamil dan ibu nifas diminta untuk memilih sumber informasi apa saja yang digunakan untuk mendapatkan informasi tentang COVID - 19. Sedangkan analisa data menggunakan distribusi frekuensi.

\section{Hasil dan Pembahasan}

Tabel 1. Distribusi frekuensi sumber informasi COVID-19 pada ibu hamil dan ibu nifas

\begin{tabular}{|c|c|c|c|c|}
\hline \multirow[t]{3}{*}{ Sumber informasi } & \multicolumn{4}{|c|}{ Frekuensi } \\
\hline & \multicolumn{2}{|c|}{ Ibu Hamil } & \multicolumn{2}{|c|}{ Ibu Nifas } \\
\hline & $f$ & $\%$ & $f$ & $\%$ \\
\hline Berita Televisi & 25 & 83 & 18 & 78 \\
\hline $\begin{array}{l}\text { Berita website } \\
\text { pemerintah }\end{array}$ & 3 & 10 & 9 & 39 \\
\hline Tenaga Kesehatan & 10 & 33 & 9 & 39 \\
\hline Sosial Media & 21 & 70 & 17 & 74 \\
\hline $\begin{array}{l}\text { Tetangga atau } \\
\text { keluarga }\end{array}$ & 11 & 37 & 8 & 35 \\
\hline Lain-lain & 5 & 17 & 5 & 22 \\
\hline
\end{tabular}

Sumber informasi COVID-19 pada ibu hamil dan ibu nifas di kecamatan Baturraden yang dapat kita lihat pada table 1 , terbanyak pertama adalah televisi. Sebuah studi melaporkan bahwa televisi merupakan sumber informasi kedua terbanyak yang di akses masyarakat untuk mendapatkan informasi tentang COVID-19 (Yunus \&
Zakaria, 2021). Studi lain di Amerika serikat melaporkan bahwa sumber informasi melalui media tradisional yang mencakup televisi, radio, podcast atau surat kabar adalah sumber informasi COVID-19 yang terbanyak (Ali et al., 2020). Sebuah studi menyatakan bahwa masyarakat Malaysia, menggunakan portal berita dari televisi dan internet sebagai pilihan utama untuk mengakses informasi tentang COVID-19 (Mohamad et al., 2020).

Sebuah studi di Shenzhen China menyatakan bahwa paparan sumber informasi yang berbeda dapat memberikan pengaruh yang berbeda pada kesehatan mental dan perubahan perilaku. Setelah mengontrol variabel pendahulu yang signifikan, paparan informasi yang lebih tinggi melalui televisi dan surat kabar berasosiasi dengan kualitas tidur yang lebih baik dan kepatuhan yang lebih tinggi dalam menjaga kebersihan tangan. Di China, televisi, surat kabar dan majalah adalah media tradisional yang paling banyak dioperasikan oleh pemerintah, sehingga informasi yang disampaikan sudah melalui verifikasi oleh sumber ahli. Pemerintah juga menyebarkan informasi tentang rencana, tindakan dan pengendalian COVID-19. Informasi tersebut dapat membantu membangun kepercayaan masyarakat terhadap kemampuan pemerintah untuk memberantas COVID-19 sehingga dikaitkan dengan adaptasi masyarakat terhadap tindakan pencegahan dan kesehatan mental selama masa pandemi (Pan et al., 2020).

Sebuah studi melaporkan bahwa televisi merupakan sumber informasi yang paling banyak di akses oleh masyarakat dengan pengetahuan yang baik tentang COVID-19 (Yunus \& Zakaria, 2021). Studi lain melaporkan bahwa sebagian masyarakat mencari informasi tentang COVID-19 melalui televisi, hanya di awal masa pandemi saja, dan karena merasa bosan dengan informasi tentang COVID-19 yang semakin banyak, upaya pencarian informasi tersebut tidak berlanjut lagi bagi sebagian masyarakat (Yunarti \& Harmaningsih, 2020).

Sebagian responden menyatakan alasan mencari informasi melalui televisi adalah informasi yang disampaikan akurat, terutama informasi yang ditayangkan pada program berita. Masyarakat menilai bahwa 
sebelum informasi disebarluaskan kepada masyarakat dalam tayangan televisi, informasi telah di periksa terlebih dahulu, sehingga data yang disampaikan akurat. Namun sebagian responden yang lain menilai bahwa ada kalanya berita yang disampaikan melalui televisi tidak valid karena informasi yang disampaikan tidak cukup jelas (Yunarti \& Harmaningsih, 2020). Sebuah survei secara online melaporkan bahwa sumber atau platform yang ditemukan kesalahan informasi tentang COVID-19 terbanyak kedua menurut responden adalah televisi (Gupta et al., 2020).

Sosial media adalah komunikasi elektronik, dimana penggunanya membuat suatu komunitas online untuk berbagi informasi, ide, pesan pribadi atau konten lainnya (Gottlieb \& Dyer, 2020). Beberapa platform yang fokus pada sosial media adalah facebook, Instagram, twitter, youtube, tiktok, whatsapp, chat dan sebagainya (Sathish et al., 2020).

Hasil penelitian ini (table 1) menunjukkan bahwa sumber informasi COVID-19 pada ibu hamil dan ibu nifas di kecamatan Baturraden, terbanyak kedua adalah sosial media. Sebuah studi melaporkan bahwa 94,9 \% responden menggunakan sosial media sebagai sumber informasi COVID-19 (Findayani, 2020), studi lain melaporkan bahwa sosial media adalah sumber informasi terbanyak diakses oleh masyarakat untuk mencari informasi tentang COVID-19 (Yunus \& Zakaria, 2021) dan studi di Amerika serikat melaporkan bahwa sosial media merupakan sumber informasi terbanyak ke tiga, yang di akses responden untuk mendapatkan informasi tentang COVID-19 (Ali et al., 2020).

Sosial media dapat dimanfaatkan untuk memfasilitasi distribusi informasi baru kepada penyedia layanan di garis terdepan. Sosial media efektif mempersingkat waktu publikasi untuk penyebaran dan penerapan informasi tersebut. Untuk menghadapi informasi yang berubah secara cepat, sosial media dapat memfasilitasi penyedia layanan agar mendapatkan informasi yang up to date dan berbasis bukti (Gottlieb \& Dyer, 2020).

Sosial media juga memungkinkan pemimpin dalam pelayanan kesehatan untuk berinteraksi secara langsung dengan masyarakat dan berbagi informasi kesehatan untuk meningkatkan kesadaran masyarakat tentang perawatan kesehatan (Gottlieb \& Dyer, 2020). Pada penelitian ini, ibu hamil dan ibu nifas yang memilih sosial media sebagai sumber informasi COVID-19, beberapa diantaranya (19 \% ibu hamil dan $41 \%$ ibu nifas), juga mencari informasi tentang COVID-19 melalui akun sosial media dari Kementrian Kesehatan atau Pejabat Publik.

Keterbatasan utama dari sosial media adalah sulit menyaring informasi yang dibagikan atau sulit mengidentifikasi informasi mana yang relevan dan faktual, sejalan dengan banyaknya informasi yang di bagikan melalui sosial media. Public figure dengan pengikut yang banyak, dapat membagikan informasi secara cepat kepada follower, terlepas dari kebenaran informasi tersebut, sehingga dapat menyebabkan penyebaran informasi yang tidak benar secara cepat (Gottlieb \& Dyer, 2020). Ada banyak kemungkinan penyebaran informasi palsu, rumor atau misinformasi pada sosial media, karena tidak ada batasan atau pembatasan yang hanya dipermukaan terhadap indivudu pengguna dalam membuat konten atau memposting ke publik (Sathish et al., 2020). Sebuah survei secara online melaporkan bahwa sumber atau platform yang ditemukan kesalahan informasi tentang COVID-19 terbanyak menurut responden adalah sosial media (Gupta et al., 2020).

Sebuah studi di Amerika Serikat melaporkan bahwa sumber informasi tentang COVID-19 dari pemerintah adalah yang terbanyak di akses oleh masyarakat setempat dan merupakan sumber informasi yang paling terpercaya menurut masyarakat (Ali et al., 2020). Sebuah studi di Malaysia melaporkan bahwa sumber informasi tetang COVID-19 yang terbanyak diakses adalah dari Kementrian Kesehatan, karena Kementrian Kesehatan adalah pemegang otoritas lokal dalam kesehatan masyarakat dan sumber informasi utama tentang COVID-19 (Mohamad et al., 2020). Namun hal tersebut tidak sesuai dengan hasil penelitian ini, yaitu ibu hamil yang mengakses berita dari website pemerintah hanya $10 \%$ (peringkat ke enam) dan ibu nifas yang mengakses berita dari website 
pemerintah $39 \%$ (peringkat ke tiga atau keempat).

COVID-19 adalah peyakit baru bagi masyarakat, dengan daya penularan yang cukup tinggi sehingga dalam waktu beberapa bulan saja sudah menyebar ke berbagai negara di dunia. Oleh karenanya setiap lapisan masyarakat harus memperoleh informasi yang memadai tentang apa itu COVID-19, bagaimana penularan, bagaimana pencegahan dan bagaimana penanganannya untuk dapat menjaga diri sendiri, keluarga dan lingkungan dari paparan COVID-19. Sumber informasi memiliki peranan penting dalam meningkatkan pengetahuan masyarakat termasuk ibu hamil dan ibu nifas tentang COVID-19. Setiap sumber informasi memiliki manfaat dan keterbatasan masing-masing, sehingga masyarakat termasuk ibu hamil dan ibu nifas harus lebih waspada terhadap informasi yang diterima, harus melakukan klarifikasi ulang terhadap kebenaran informasi tersebut sebelum menggunakannya sebagai pedoman.

Tabel 2. Distribusi frekuensi jumlah sumber informasi COVID-19 pada ibu hamil dan ibu nifas

\begin{tabular}{ccccc}
\hline $\begin{array}{c}\text { Jumlah sumber } \\
\text { informasi }\end{array}$ & \multicolumn{4}{c}{ Frekuensi } \\
& lbu hamil & \multicolumn{2}{l}{ lbu nifas } \\
& $\mathrm{f}$ & $\%$ & $\mathrm{f}$ & $\%$ \\
\hline 1 & 9 & 30 & 7 & 31 \\
2 & 9 & 30 & 5 & 22 \\
3 & 6 & 20 & 2 & 9 \\
4 & 1 & 3 & 4 & 17 \\
5 & 5 & 17 & 4 & 17 \\
6 & 0 & 30 & 1 & 4 \\
Total & 30 & 100 & 23 & 100 \\
\hline
\end{tabular}

Pada table 2 dapat kita lihat jumlah sumber informasi COVID-19 pada ibu hamil, mayoritas adalah satu dan dua sumber informasi dengan prosentase sama, sedangkan jumlah sumber informasi COVID-19 pada ibu nifas mayoritas adalah satu sumber informasi. Masing-masing sumber informasi memiliki keterbatasan yang memungkinkan munculnya pesan yang palsu (hoax), rumor atau misinformasi, sehingga penerima informasi harus melakukan konfirmasi terhadap sumber informasi lain untuk mengetahui kebenarannya. Semakin banyak sumber informasi yang di akses ibu hamil dan ibu nifas tentang COVID-19, semakin besar kemungkinan mendapatnya informasi yang faktual dan relevan. Oleh karena itu, akses ibu hamil dan ibu nifas terhadap sumber informasi yang lebih variatif perlu di tingkatkan.

Sebuah studi di China memberikan bukti empiris tentang bagaimana jumlah, sumber dan isi informasi yang di akses oleh responden dapat mempengaruhi kesehatan mental dan kepatuhan mereka terhadap tindakan pencegahan dari individu tersebut pada tahap awal dimulainya kembali periode bekerja. Kualitas informasi (kebenaran informasi) memiliki peranan penting untuk memodifikasi asosiasi antara keterpaparan informasi dengan kesehatan mental (Pan et al., 2020). Selama masa pandemi, mengelola informasi dan menjaga kepercayaan publik adalah perihal yang sangat penting. Pemegang otoritas kesehatan harus memberikan perhatian yang besar pada penggunaan saluran media dan sumber informasi yang tepat untuk menyebarluaskan informasi penting kepada publik secara efektif (Mohamad et al., 2020).

Sebuah studi melaporkan bahwa sumber informasi COVID-19 sangat di tentukan oleh karakteristik sosiodemografi responden serta berasosiasi dengan pengetahuan dan keyakinan responden tentang pandemi. Temuan tersebut menyoroti dampak penggunaan berbagai sumber informasi yang berbeda dan terpercaya. Banyak file sumber informasi yang tidak konsisten, menyebabkan sumber, jenis dan kebenaran informasinya sangat bervariasi, sehingga perbedaan tersebut harus dipertimbangkan ketika menafsirkan temuan. Misalnya masyarakat dapat mengakses berbagai sumber informasi berbasis internet, baik situs non-resmi atau non-pemerintah, tentunya ada yang memberikan informasi yang valid dan terkini tentang COVID-19 (Ali et al., 2020). Semakin banyak sumber informasi yang di akses oleh ibu hamil dan ibu nifas, semakin banyak informasi pembanding, sehingga dapat membedakan informasi yang valid dengan informasi yang palsu (hoax).

Sebuah studi melaporkan bahwa sumber informasi secara signifikan berhubungan dengan tingkat pengetahuan 
tentang COVID-19. Pengetahuan merupakan salah satu domain yang penting dalam membentuk suatu tindakan (Yunus \& Zakaria, 2021), dalam hal ini tindakan atau perilaku pecegahan COVID-19. Studi lain melaporkan bahwa pengetahuan tentang COVID-19 secara signifikan berhubungan dengan kecemasan ibu hamil pada masa pandemi COVID-19 (Septiasari \& Viandika, 2021). Sehingga sumber informasi yang baik akan mempengaruhi pengetahuan ibu hamil dan ibu nifas tentang COVID-19 serta berpengaruh terhadap kecemasan ibu.

\section{Kesimpulan}

Kesimpulan dari studi ini adalah sumber informasi tentang COVID-19 yang terbanyak di akses oleh ibu hamil dan ibu nifas di Kecamatan Baturraden adalah televisi dan sosial media. Sedangkan jumlah sumber informasi COVID-19 yang di akses oleh ibu hamil terbanyak adalah satu dan dua sumber informasi, sedangkan jumlah sumber informasi COVID-19 yang di akses ibu nifas terbanyak adalah satu sumber informasi. Ibu hamil dan ibu nifas harus mengakses lebih banyak sumber informasi dan mempertimbangkan kebenarannya agar mendapatkan informasi yang faktual, valid dan relevan.

\section{Ucapan Terima Kasih}

Kami menyampaikan ucapan terima kasih kepada Kepala Dinas Kesehatan Kabupaten Banyumas, Direktur Poltekkes Kemenkes Semarang Kepala Puskesmas I Baturraden, Kepala Puskesmas II Baturraden beserta jajarannya yang telah mengijinkan pelaksanaan penelitian serta memfasilitasi pembiayaan penelitian.

\section{Daftar Pustaka}

Ali, S. H., Foreman, J., Tozan, Y., Capasso, A., Jones, A. M., \& DiClemente, R. J. (2020). Trends and predictors of COVID-19 information sources and their relationship with knowledge and beliefs related to the pandemic: nationwide cross-sectional study. JMIR Public Health and Surveillance, 6(4), e21071.
Dewi, R., Widowati, R., \& Indrayani, T. (2020). Pengetahuan dan sikap ibu hamil trimester III terhadap pencegahan Covid-19. Health Information: Jurnal Penelitian, 12(2), 131-141.

Direktorat Kesehatan Keluarga. (2020). Pedoman Bagi Ibu Hamil, Ibu Nifas, dan Bayi Baru Lahir Di Era Pandemi Covid-19.

http://www.kesga.kemkes.go.id/images/ pedoman/Pedoman bagi lbu Hamil, Bersalin, Nifas dan BBL di Era Pandemi COVID 19.pdf

Findayani, A. (2020). Sosial Media sebagai Upaya Penguranagan Risiko Bencana Covid 19 (Studi Kasus Kota Semarang).

Gottlieb, M., \& Dyer, S. (2020). Information and Disinformation: Social Media in the COVID-19 Crisis. Academic Emergency Medicine, 27(7), 640-641.

Gupta, L., Gasparyan, A. Y., Misra, D. P., Agarwal, V., Zimba, O., \& Yessirkepov, M. (2020). Information and misinformation on COVID-19: a cross-sectional survey study. Journal of Korean Medical Science, 35(27).

Hutagaol, I. O., \& Sihotang, P. C. (2020). Peningkatan Pengetahuan Pada lbu Hamil Dan Nifas Sebagai Upaya Pencegahan Covid 19 Di Puskesmas Sangurara. JTCSA ADPERTISI JOURNAL, 1(1), 67-78.

Kemenkes. (2020). Pedoman Bagi Ibu Hamil, Ibu Nifas Dan Bayi Baru Lahir Selaam Sosial Distancing. In Pedoman Bagi Ibu Hamil , Ibu Nifas dan Bayi Baru Lahir Selama Covid-19.

Mohamad, E., Tham, J. S., Ayub, S. H., Hamzah, M. R., Hashim, H., \& Azlan, A. A. (2020). Relationship Between COVID-19 Information Sources and Attitudes in Battling the Pandemic Among the Malaysian Public: Cross-Sectional Survey Study. Journal of Medical Internet Research, 22(11), e23922.

Mubarak, W. I., \& Chayatin, N. (2009). IImu kesehatan masyarakat: teori dan aplikasi. Jakarta: Salemba Medika, 393.

Pan, Y., Xin, M., Zhang, C., Dong, W., Fang, Y., Wu, W., Li, M., Pang, J., Zheng, Z., \& Wang, Z. (2020). Associations between COVID-19 specific information exposure, mental health and 
self-reported compliance with personal preventive measures: evidence from a cross-sectional study at the initial phase of work resumption following the COVID-19 outbreak in Chi. J. Med. Internet Res.

POKJA Infeksi Saluran Reproduksi PP POGI. (2020). Update Rekomendasi POGI: Penanganan Infeksi Virus Corona (COVID-19) Pada Maternal (Hamil, Bersalin Dan Nifas) Dalam Masa New Normal Revisi 2.

Sathish, R., Manikandan, R., Priscila, S. S., Sara, B. V. J., \& Mahaveerakannan, R. (2020). A Report on the Impact of Information Technology and Social Media on Covid-19. 2020 3rd International Conference on Intelligent Sustainable Systems (ICISS), 224-230.

Satuan Tugas Penanganan COVID-19. (2021). Peta Sebaran COVID-19. https://covid19.go.id/peta-sebaran-covi d19

Septiasari, R. M., \& Viandika, N. (2021). The Correlation between Covid-19 Knowledge and Anxiety of Pregnant Women During Covid-19 Pandemic. JI-KES (Jurnal IImu Kesehatan), 4(2), 71-74.
Siregar, R. N., Aritonang, J., \& Anita, S. (2020). Pemahaman Ibu Hamil Tentang Upaya Pencegahan Infeksi COVID-19 Selama Kehamilan. Journal Of Healthcare Technology And Medicine, 6(2), 798-805.

Tim Komunikasi KPCPEN. (2020). Memahami Perilaku dan Informasi Tepat untuk Mencegah Penularan COVID-19.

https://covid19.go.id/p/berita/memaham i-perilaku-dan-informasi-tepat-untuk-me ncegah-penularan-covid-19

Yunarti, S., \& Harmaningsih, D. (2020). Pencarian Informasi Covid-19 pada Masyarakat Urban. Fikom UPI YAI.

Yunus, M., \& Zakaria, S. (2021). Sumber Informasi Berhubungan dengan Pengetahuan Masyarakat tentang Covid-19. Jurnal Keperawatan, 13(2), 337-342. 